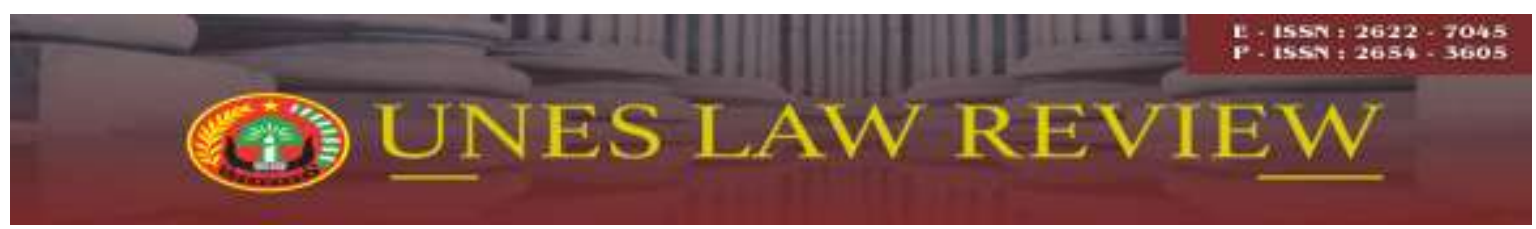

Email: uneslawreview@gmail.com

Online: http://review-unes.com/index.php/law

Volume 2, Issue 1, September 2019

\title{
PEMENUHAN HAK ANAK SEBAGAI TERSANGKA DALAM PENYIDIKAN TINDAK PIDANA KECELAKAAN LALU LINTAS
}

\author{
Afrino \\ Program Magister Ilmu Hukum, Universitas Ekasakti, Padang \\ E-mail : afrino@gmail.com
}

\begin{abstract}
Lately, there have been frequent traffic accidents which have caused many losses. The Sijunjung Regional Police Laka Satlantas Unit has handled 35 cases of traffic accident committed by children, so far it has always prioritized child protection in examining children who are dealing with the field of law. This research is a descriptive analytical study. Adapaun the results of the implementation of the implementation of the fulfillment of children's rights as suspects in the investigation process, can be seen from careful actions carried out by investigators, meaning that if the cases carried out by children are still classified as minor acts, there should be no detention measures, whereas if the case is a criminal offense detention can be carried out, in the investigation process the suspect must be accompanied by his parents even though his legal advisor does not come to accompany the suspect. BAPAS in the inspection phase is obliged to assist the suspect. Examination of child suspects, it should be noted that there is a special room that is comfortable and friendly for child offenders, and the Diversion process is prioritized to achieve the best interests for children. Constraints encountered by the police in fulfilling children's rights as suspects in the process of investigating traffic accident crimes, namely in the process of investigating and detaining suspected children, where there are internal factors, namely members of Unit Laka personnel who are few in number, BAPAS sometimes unable to attend, legal counsel sometimes unable to attend. Efforts to overcome the obstacles that arise in the provision of children's rights as suspects in the investigation process of traffic accident crimes, where the Sijunjung Regional Police have dealt with these obstacles in accordance with what is needed, among others asking for funds to add detention rooms, writing BAPAS and legal counsel, and providing socialization to schools or to the community regarding enforcement of traffic laws in general and the protection of children in particular.
\end{abstract}

Kata Kunci: Hak Anak, Penyidikan, Lalu Lintas, Polres Sijunjung

\section{PENDAHULUAN}

Akhir-akhir ini, sering terjadi kecelakaan lalu lintas yang banyak menimbulkan kerugian. Kerugian secara fisik maupun kerugian secara materi. Secara fisik pelaku maupun korban kecelakaaan lalu lintas dapat mengalami luka ringan, luka berat, dan juga 
dapat menimbulkan kematian. Secara materi, kecelakaan lalu lintas dapat menimbulkan kerusakan pada kendaraan bermotor yang digunakan pelaku maupun korban serta dapat menimbukan kerusakan terhadap fasilitas-fasilitas umum (Emiliana, 59:2005).

Kecelakaan lalu lintas dapat juga dialami oleh anak-anak.Anak- anak dapat menjadi korban kecelakaan lalu lintas serta perbuatan anak-anak dapat mengakibatkan korban dalam kecelakaan lalu lintas tersebut. Anak-anak yang menjadi korban kecelakaan lalu lintas maupun yang menjadi penyebab adanya korban dalam kecelakaan lalu lintas dapat dihadapan pada pertanggung jawaban hukum (Gatot Supramono, 9:2000). Sebagai korban, anak tersebut dapat meminta pertanggung jawaban dari pelaku untuk memenuhi hak-hak anak tersebut sebagai korban. Sedangkan anak yang menjadi penyebab adanya korban dalam kecelakaan lalu lintas harus mempertanggung jawabankan perbuatannya berdasarkan peraturan perundang-undangan yang berlaku.

Keberadaan Undang-undang Nomor 11 Tahun 2012 tentang Sistem Peradilan Pidana Anak memberi jaminan perlindungan terhadap anak. Anak perlu mendapatkan perlakuan hukum khusus, terutama ketika anak melakukan suatu tindak pidana (Alghiffari, 3:2012). Untuk menjamin penegakan hak anak tersebut, anak juga harus memperoleh perhatian dan pengawasan mengenai tingkah lakunya, karena anak dapat melakukan perbuatan yang tidak terkontrol, merugikan orang yang disekitarnya atau merugikan dirinya sendiri(Gusti Ayu, 13:2013).

Berbagai masalah tindak pidana kecelakaan lalu lintas yang terjadi belakangan ini terutama tindak pidana yang dilakukan oleh anak, dimana dalam tahap penyidikan masih ada anak yang belum mendapatkan haknya dimana dalam proses penyidikan penyidik wajib memeriksa tersangka anak dalam suasana kekeluargaan (Pasal 18 Undang-undang Nomor 11 Tahun 12 tentang Sistem Peradilan Pidana Anak), dengan contoh kasus sebagai berikut, bahwa Sat Lantas Polres Sijunjung menerima 75 laporan kasus yang tersangkanya dilakukan oleh anak pada tahun 2015 sampai dengan 2018.

Ada beberapa contoh kasus yang terjadi yaitu: Pada hari senin tanggal 3 September 2018 terjadi kecelakaan. Muhammad Rhedo yang berumur 17 tahun menabrak seorang pengendara motor yang bernama Samsuar yang berumur 52 tahun, korban tersebut meninggal dunia pada tanggal 4 September 2018. Tanggal 25 Juli terjadi penganiayaan (Pasal 351 KUHP) yang dilakukan oleh David (umur 17 tahun) kepada Ryanda Varelinno 
(umur 12 tahun) akibat terjadi senggolan motor, menyebabkan korban luka-luka dan sempat dirawat di ruumah sakit.

Berdasarkan latar belakang yang telah diuraikan di atas dapat dirumuskan beberapa permasalahan yang akan dibahas dalam penelitian yaitu: Bagaimana pemenuhan hak anak sebagai tersangka dalam proses penyidikan tindak pidana kecelakaan lalu lintas? Apa saja kendala yang ditemui pihak kepolisian dalam pemenuhan hak anak sebagai tersangka dalam proses penyidikan tindak pidana kecelakaan lalu lintas? Bagaimanakah upaya menanggulangi kendala yang timbul dalam pemberian hak anak sebagai tersangka dalam proses penyidikan tindak pidana kecelakaan lalu lintas?

\section{METODE PENELITIAN}

Penelitian ini merupakan penelitian deskriptif analitis. Pendekatan yang digunakan dalam penelitian ini adalah pendekatan yuridis normatif yang didukung pendekatan yuridis empiris. Data yang digunakan dalam penelitian ini yaitu data sekunder dan data primer. Terhadap semua data dan bahan yang diperoleh dari hasil penelitian disusun dan dianalisis secara kualitatif, dan disajikan dalam bentuk deskriptif kualitatif.

\section{HASIL PENELITIAN DAN ANALISIS}

\section{Pemenuhan Hak Anak Sebagai Tersangka Dalam Proses Penyidikan Tindak Pidana Kecelakaan Lalu Lintas Di Sat Lantas Polres Sijunjung}

Proses pemeriksaan terhadap tersangka anak merupakan bagian dari kegiatan penyidikan yang bertujuan untuk mendapatkan keterangan, kejelasan dan keidentikan tersangka dan barang buktinya. Juga diperlukan kemampuan khusus yang harus dimiliki oleh pemeriksa sehingga dalam pelaksanaannya perlakuan-perlakuan yang diberikan kepada anak harus dibedakan dengan tersangka dewasa. Dalam proses pemeriksaan wajib dilaksanakan dengan menjunjung tingggi hukum yang berlaku serta senantiasa memperhatikan hak asasi manusia sebagaimana diatur dalam KUHAP. Menurut MR (umur 17 tahun) selaku tersangka penabrakan menyatakan bahwa: Ketika tahap pemeriksaan, pemeriksaan dilakukan di ruang Unit Laka Lantas dan di dalam ruangan tersebut hanya ada tersangka dan seorang Polisi selaku penyidik anak dan tidak berpakaian dinas. 
Untuk melakukan pemeriksaan tersangka anak maka yang perlu diperhatikan adalah ruangan unit Laka Lantas Polres Sijunjung, pemeriksaan tersangka yang memungkinkan terselenggaranya proses pemerikasaan, dalam rangka mengungkap perkara yang sedang disidik. Selain itu anak dalam proses pemeriksaan didampingi oleh orang tuanya dan BAPAS (Balai Pemasyaraktan) agar menjamin pemenuhan perlindungan hak anak dalam proses penyidikan, dan tersangka mengetahui apa saja hak yang harus dilindungi oleh kepolisian pada saat penyidikan oleh penyidik Polres Sijunjung.

Pemeriksaan tersangka anak di wilayah Polres Sijunjung dilakukan di ruangan khusus yang berdasarkan dengan kacamata Penulis mengindikasikan bahwa ruangan tersebut cukup aman karena berada dalam ruangan yang dilengkapi dengan air conditioner yang diharapkan agar dalam pemeriksaan anak dapat dilakukan dalam suasana yang sejuk dan nyaman. Untuk mencerminkan situasi kekeluargaan dalam melakukan pemeriksaan anak yang berkonflik dengan hukum, salah satu upaya yang dilakukan adalah menggunakan fasilitas yang dapat membuat anak tersebut tidak merasa takut.

Dalam hal pertanggung jawaban atas perbuatan pidana yang dilakukan oleh anak dapat diminimalisirkan dengan upaya diversi, upaya diversi ini merupakan pengalihan perkara di luar peradilan, sehingga umur 12-15 yang dianggap kemampuan berpikir lemah bisa dilakukan pelajaran berupa hukuman bukan hukuman pidana sedangakan umur 15-18 tahun ini juga bisa dibantu akan adanya diversi ini, apalagi usia anak 12-18 merupakan usia anak untuk memperoleh hak pendidikan untuk menjadi manusia yang berguna bagi nusa, bangsa, keluarga, masyarakat dan agama.

Proses diversi ini dapat mengandung unsur rela berkorban yakni pihak keluarga korban rela berkorban bahwa perkaranya tidak dilanjutkan sampai ke meja pengadilan dan pelaku tidak mendapat hukuman sesuai dengan yang ada di KUHP maupun di UU Nomor 11 Tahun 2012 tentang Sistem Peradilan Pidana Anak karena sudah ada kesepakatan di luar peradilan.

Selain itu menurut ketentuan hukum pidana, seseorang atau subjek hukum pidana yang lain yang telah dinyatakan terbukti bersalah melakukan suatu tindak pidana dan memenuhi kemampuan bertanggungjawab serta tidak ada alasan penghapus penuntutan maupun alasan penghapus pemidanaan harus dijatuhi sanksi berupa pidana, demikian halnya terhadap anak yang telah terbukti bersalah melakukan suatu tindak pidana termasuk 
dalam kecelakaan lalu lintas yang mengakibatkan orang lain meninggal harus dijatuhi sanksi. Sanksi yang dapat dijatuhkan terhadap orang dewasa berbeda dengan anak.

Sanksi terhadap anak diatur dalam ketentuan Pasal 71 Undang- Undang Nomor 11 Tahun 2012, sebagai berikut:

1. Pidana pokok bagi Anak terdiri atas :

a. pidana peringatan;

b. pidana dengan syarat:

1) pembinaan di luar lembaga;

2) pelayanan masyarakat; atau

3) pengawasan.

c. pelatihan kerja;

d. pembinaan dalam lembaga; dan

e. penjara.

2. Pidana tambahan terdiri atas:

a. perampasan keuntungan diperoleh dari tindak pidana; atau

b. pemenuhan kewajiban adat yang

3. Apabila dalam hukum materiil diancam pidana kumulatif berupa penjara dan denda, pidana denda diganti dengan pelatihan kerja.

4. Pidana yang dijatuhkan dilarang melanggar harkat dan martabat Anak.

5. Ketentuan lebih lanjut mengenai bentuk dan tata cara pelaksanaan pidana sebagaimana dimaksud pada ayat (1), ayat (2), dan ayat (3) diatur dengan Peraturan Pemerintah.

Berdasarkan ketentuan Pasal 1 angka 3 jo Pasal 71 ayat (2) huruf a dan b jo Pasal 69 ayat (2) Undang-Undang Nomor 11 Tahun 2012 Anak yang berkonflik dengan hukum yang selanjutnya disebut anak adalah anak yang telah berumur 12 (dua belas) tahun, tetapi belum berumur 18 (delapan belas) tahun yang diduga melakukan tindak pidana. Anak yang dapat dijatuhi pidana adalah anak yang berusia di atas 14 (empat belas) tahun dan tindak pidana yang dilakukan oleh anak adalah tindak pidana yang diancam dengan pidana penjara selama 7 (tujuh) tahun sehingga terhadap anak walaupun sudah berusia 14 (empat belas) tahun apabila tindak pidana yang dilakukan diancam dengan pidana penjara, maka terhadap anak tersebut tidak dapat dijatuhi pidana, melainkan dijatuhi tindakan sebagaimana disebutkan dalam ketentuan Pasal 82 Undang Undang Nomor 11 Tahun 2012. Oleh karena dalam kecelakaan lalu lintas jalan yang mengakibatkan orang lain meninggal dunia diancam dengan pidana penjara paling lama 6 (enam) tahun dan atau denda paling banyak Rp.12.000.000 (Duabelas juta rupiah) dibawah 7 (tujuh) tahun tetapi hanya dapat dijatuhi tindakan. maka terhadap anak tidak dapat dijatuhi pidana. 
Kendala yang Ditemui Pihak Sat Lantas Polres Sijunjung dalam Pemenuhan Hak Anak Sebagai Tersangka dalam Proses Penyidikan Tindak Pidana Kecelakaan Lalu Lintas

Kendala yang ditemui pihak kepolisian dalam pemenuhan hak anak sebagai tersangka dalam proses penyidikan tindak pidana kecelakaan lalu lintas bisa dilihat dalam proses penydikannya, dimana proses pemeriksaan terhadap tersangka anak merupakan bagian dari kegiatan penyidikan yang bertujuan untuk mendapatkan keterangan, kejelasan dan keidentikan tersangka dan barang buktinya. Juga diperlukan kemampuan khusus yang harus dimiliki oleh pemeriksa sehingga dalam pelaksanaannya perlakuan-perlakuan yang diberikan kepada anak harus dibedakan dengan tersangka dewasa. Dalam proses pemeriksaan wajib dilaksanakan dengan menjunjung tingggi hukum yang berlaku serta senantiasa memperhatikan hak asasi manusia sebagaimana diatur dalam KUHAP.

Menurut kaca mata penulis saat melakukan penelitian lapangan terhadap tindak pidana yang tersangkanya adalah anak, ada beberapa kendala yang dialami pada saat melakukan proses penyidikan di Satlantas Polres Sijunjung, dibagi menjadi 2 faktor, yaitu antara lain:

\section{Faktor Intern}

Pada proses penyidikan tersangka harus didampingi oleh orang tua kandungnya, penasehat hukum tersangka anak, serta BAPAS (Balai Pemasyarakatan) agar menjamin pemenuhan perlindungan hak anak dalam proses penyidikan. Pada proses ini tersangka anak diperiksa didalam ruangan unitPelayan Perempuan dan Anak (PPA), pemeriksaan tersangka yang memungkinkan terselenggaranya proses pemerikasaan, dalam rangka mengungkap perkara yang sedang disidik. Adapun kendala-kendala yang terjadi pada faktorn instern ini, antara lain adalah:

a. Kendala pada penasehat hukum, penasehat hukum terhadap tersangka anak sering tidak mendampingi kliennya, disaat polisi membuat Berita Acara Pemeriksaan terhadap tindak pidana yang dilakukan oleh anak. Akibat penasehat hukum tidak hadir atau terlambat maka pembuatan Berita Acara Pemeriksaan terhadap mejadi terlambat, karena menunggu kehadiran dari penasehat hukum.

b. BAPAS di Sumatera Barat hanya ada dua, yaitu BAPAS Bukittinggi dan BAPAS Padang. Wilayah hukum Sijunjung sendiri akan selalu bekerjasama dengan BAPAS Padang. Pada saat BAPAS Padang tidak bisa menghadiri mediasi pada saat 
melakukan diversi terhadap anak pelaku tindak pidana ini, maka pelaksanaa diversi ataupun proses mediasi tidak bisa dilanjutkan.

c. Anggota penyidik sangat terbatas, terkadang penyidik juga merasa kelelahan, karena memiliki tugas selain memeriksa anak dalam sistem peradilan pidana anak.

2. Faktor Ekstren

Adapaun kendala dalam factor ekstern adalah sebagai berikut ini, yaitu:

a. Pada proses penyidikan terkadang si anak hanya diam saja, dan tak berbicara dengan jelas, sehingga menyulitkan penyidik dalam tahap penyidikan.

b. Pada saat mnyampaikan hak tersangka terkadang tersangka dan orang tua tidak memahami apa itu perlindungan, karena ada beberapa tersangka yang berasal dari keluarga yang tidak mengenyam bangku sekolah.

c. Pada saat melakukan proses penyidikan, orang tua tersangka kadang memarahi tersangka, sehingga membuat tersangka merasa terpojok dan tak mua berbicara.

d. Pada saat penahanan ada beberapa tersangka di dalam sel tahanan tersebut menangis terus menerus dan tidak mau makan, dan terkadang si anak bertingkah aneh. Kemungkinan hal itu terjadi karena anak merasa bersalah dan takud terhadap ancaman hukuman yang akan dikenakan padannya pada saat hakim menjatuhkan putusan pidana kepadanya di pengadilan negeri.

Upaya Menanggulangi Kendala Yang Timbul Dalam Pemberian Hak Anak Sebagai Tersangka Dalam Proses Penyidikan Tindak Pidana Kecelakaan Lalu Lintas

Upaya dari Sat Lantas untuk menekan Angka kecelakaan Anak di wilayah hukum Polres Sijunjung diantaranya adalah dengan memberikan sosialisasi tentang pemahaman keselamatan berlalu lintas dan batas minimal usia anak mengendarai kendaraan bermotor di sekolah - sekolah dengan sasaran anak dibawah umur, melakukan sosialisasi dengan sasaran orang tua dengan program polres rembang, sarasehan didesa-desa dengan tujuan pemahaman kepada Orang tua tentang pentingnya tertib berlalu lintas, dan melarang anak untuk mengendarai kendaraan sebelum usia 17 tahun serta melakukan Giat Penindakan Pelanggaran yang berpotensi laka lantas dengan sasaran Anak dibawah umur. 
Adapun upaya yang dilakukan oleh pihak penyidik Unit Laka Lantas Polres Sijunjung untuk menanggulangi kendala yang timbul dalam penegakkan hak anak dalam proses pemyidikan terhadap tersangka anak adalah:

1. Pada saat Penasehat Hukum tersangka tidak bisa hadir, penyidik Laka Lantas Polres Sijunjung anak tetap mengusahakan agar hak terhadap tersangka anak dipenuhi, dan hal itu telah diberitahukan kepada setiap penyidik penyidik Laka Sat Lantas Polres Sijunjung.

2. Pada saat BAPAS Padang tidak bisa hadir, maka penyidik Laka Sat Lantas Polres Sijunjung akan tetap memberikan hak-hak perlindungan yang seharusnya diebrikan oleh anak.

3. Adanya penahanan tersangka anak yang disamakan dengan tersangka dewasa, pihak Polres Sijunjung sudah menyampaikan kepada pihak Polda Sumatera Barat, agar dapat mengalokasikan dana untuk membagun tempat penahan khusus terhadap tersangka anak yang lebih luas.

4. Pada saat proses penyidikan, agar tersangka anak tidak diam saja, maka penyidik malakukan beberapa hal, yaitu:
a. tidak menggunakan atribut kedinasan;
b. tidak membentak anak tersebut
c. membuat kondisi sekitar lebih nyaman
d. memberikan fasilitas yang membuat tersangka anak nyaman

5. Terhadap tersangka dan keluarga tersangka yang kurang memahami tentang perlindungan, terkadang pihak penyidik akan membantu tersangka dan keluarga tersangka untuk memahami apa itu perlindungan, dengan mencontohakn bentuk-bentuk perlindungan.

6. Terhadap orang tua yang memarahi korban, pihak penyidik terkadang menvoba menahan emosi dari orang tua tersangka agar tidak memarahi tersangka.

\section{PENUTUP}

Proses pemeriksaan terhadap tersangka anak merupakan bagian dari kegiatan penyidikan yang bertujuan untuk mendapatkan keterangan, kejelasan dan keidentikan tersangka dan barang buktinya. Juga diperlukan kemampuan khusus yang 
harus dimiliki oleh pemeriksa sehingga dalam pelaksanaannya perlakuan-perlakuan yang diberikan kepada anak harus dibedakan dengan tersangka dewasa. Dalam proses pemeriksaan wajib dilaksanakan dengan menjunjung tingggi hukum yang berlaku serta senantiasa memperhatikan hak asasi manusia sebagaimana diatur dalam KUHAP.

Menurut kaca mata penulis saat melakukan penelitian lapangan terhadap tindak pidana yang tersangkanya adalah anak, ada beberapa kendala yang dialami pada saat melakukan proses penyidikan di Satlantas Polres Sijunjung, dibagi menjadi 2 faktor, yaitu antara lain: 1. Faktor Intern, 2. Faktor Ekstren.

\section{DAFTAR PUSTAKA}

Buku Teks:

Alghiffari Aqsa dan Muhammad Aqsa, Mengawal Perlindungan Anak Yang Berhadapan Dengan Hukum, LBH Jakarta, Jakarta, 2012.

Emiliana Krisnawati, Aspek Hukum Perlindungan Anak, CV.Utomo, Bandung, 2005.

Gatot Supramono, Hukum Acara Pengadilan Anak, Djambatan, Jakarta, 2000.

\section{Pustaka Primer (Jurnal dan Web)}

I Gusti Ayu Ketut Rachmi Handayani, Urgensi Perlindungan Anak Di Indonesia (Kajian Perspektif Hukum), Jurnal Bestuur, Volume 2, Edisi Februari-Mei, 2013.

Laporan Data Satuan Lalu Lintas Polres Sijunjung Tahun 2015 sampai dengan Tahun 2018.

Wawancara dengan MR Tersangka Pelaku penabrakan di Ruangan Tahanan Khusus Anak, tanggal 9 Desember 2018 jam 13.00-14.00 WIB.

Wawancara dengan Aiptu Dedi Putra, selaku Kanit Laka dan Anggota Unit Laka Satlantas Polres Sijunjung, pada tanggal 10 Desember 2018.

\section{Peraturan Undang-Undang:}

Kitap Undang-Undang Hukum Pidana (KUHP).

Undang-Undang Dasar Repubulik Indonesia Nomor 11 Tahun 2012 Tentang Sistem Peradilan Pidana Anak. 